\title{
Shock Wave Equation of State of Muscovite
}

\author{
Toshimori Sekine, ${ }^{1}$ Allan M. Rubin, ${ }^{2}$ and Thomas J. Ahrens \\ Seismological Laboratory, Califomia Institute of Technology, Pasadena
}

\begin{abstract}
Shock wave data to provide an equation of state of muscovite (initial density: $2.835 \mathrm{~g} / \mathrm{cm}^{3}$ ) were determined up to a pressure of $141 \mathrm{GPa}$. The shock velocity (Us) versus particle velocity (Up) data are fit with a single linear relationship: $U_{s}=4.62( \pm 0.12)+1.27( \pm 0.04) U_{p}(\mathrm{~km} / \mathrm{s})$. Third-order Birch-Mumaghan equation of state parameters (isentropic bulk modulus and isentropic pressure derivative of bulk modulus) are $K_{0 s}=52 \pm 4 \mathrm{GPa}$ and $\mathbf{K}^{\prime}{ }_{\mathrm{os}}=3.2 \pm 0.3$. The pressure-temperature relation along the Hugoniot suggests that muscovite may dehydrate to $\mathrm{KAlSi}_{3} \mathrm{O}_{8}$ (hollandite), corundum, and water, with a small volume change, above $80 \mathrm{GPa}$. Thermodynamic calculations of the equilibrium pressure for the dehydration yields a significantly lower value. Observed unloading paths from shock pressures up to about $80 \mathrm{GPa}$ are steeper in a density-pressure plane than the Hugoniot and become shallower with increasing shock pressure above that pressure. The changing slope may indicate that devolatilization occurs during unloading above $80 \mathrm{GPa}$. The present equation of state data for muscovite are compared with results of previously reported recovery experiments.
\end{abstract}

\section{INTRODUCTION}

Hugoniot equations of state of minerals and rocks provide the basis for describing shock wave propagation from intense explosions in the Earth and the effects of meteorite impact on the Earth and the planets, as well as contributing to our knowledge of the Earth's interior and the accretion of the Earth. Small amounts of water in the interior can be sequestered into the Earth in the form of hydrous minerals such as serpentine, brucite, amphiboles and micas. These hydrous minerals may play a critical role in controlling the partial pressure of $\mathrm{H}_{2} \mathrm{O}$ within the interior and hence affecting the lower crust and mantle rheology and melting behavior and hence the Earth's evolution. Muscovite is also among the potassium-bearing minerals that could influence the chemistry of the mantle.

Since there are no previous equation of state data available for one of the most common crustal hydrous minerals, muscovite, it was the subject of the present study. The present data complement other recent shock wave studies of the hydrous minerals [Duffy et al., 1991; Tyburczy et al., 1991].

Previously, Cummings [1968], Short [1968a,b], Hörz and Ahrens [1969], and Lambert and Mackinnon [1984] investigated the postshock response of muscovite from laboratory experiments and from material in the vicinity of underground explosions. They observed characteristic features such as kinking, mosaic extinction, melting, and vesiculation. These field and laboratory studies lacked detailed knowledge of the equation of state of muscovite. Moreover, studies of the equation of state of granite rocks, and their syntheses, require shock wave data for constituent minerals.

\section{EXPERIMENT}

The natural muscovite of the present study was from Methuen Township, Ontario (Harvard University Mineralogical Museum, Cat. \#112791). The composition is listed in Table 1. The approximate size is about $40 \times 50 \times 2 \mathrm{~mm}$. The average crystal

\footnotetext{
TPermanent affiliation is National Institute for Research in Inorganic Materials, Tsukuba, Ibaraki, Japan.

${ }^{2}$ Now at Department of Geological Sciences, Brown University, Providence, Rhode Island.

Copyright 1991 by the American Geophysical Union.
}

Paper number 91JB02253.

0148-0227/91/91JB-02253\$05.00 density, determined by Archimedean method, was $2.8346 \pm 0.0026 \mathrm{~g} / \mathrm{cm}^{3}$. This is in good agreement with $X$ ray density measured for a muscovite with a similar composition [Vaughan and Guggenheim, 1986]. The entire sample was imbedded in epoxy resin and cut into rectangular aliquots $(7 \mathrm{x}$ $13 \times 2 \mathrm{~mm}$ ).

Shock loading was conducted with the Caltech $25-\mathrm{mm}$ twostage light gas gun using metal flyer plate bearing projectiles to impact samples at speeds of up to $6.3 \mathrm{~km} / \mathrm{s}$. Projectile velocity just prior to impact was determined by double-exposure flash $X$ ray photography using two 15-ns flash X ray sources and electronic time interval counters [Jeanloz and Ahrens, 1977]. Shock wave velocities in the target and buffer materials were determined by recording the destruction time of the mirrors using an image converter streak camera and xenon light source [Ahrens, 1987]. The Caltech 40-mm propellant gun [Ahrens et al., 1969] was used to accelerate Lexan projectiles fitted with either $\mathrm{Cu}$ or $\mathrm{Ta}$ flyer plates up to velocities of $2.4 \mathrm{~km} / \mathrm{s}$. Projectile velocities were measured using flash $\mathrm{X}$ ray images. Sample and buffer mirror shock velocities were obtained from observations of shock-induced loss of mirror reflectivity at successive reflective surfaces as recorded by a rotating-mirror streak camera.

The flyer and driver plates used in this study were the same to obtain symmetric impact conditions. The assumed equation of state parameters are listed in Table 2 . The particle velocity behind the shock front and pressure-density states were calculated through the impedance match method and the Rankine-Hugoniot equations, respectively. Uncertainties were determined by standard error propagation techniques [e.g. Jackson and Ahrens, 1979].

Partial release states were obtained by measuring the shock wave transit time through low-impedance buffers in contact with the sample. The pressure and particle velocity at the buffer-sample interface were determined from the measured shock velocity and the known equation of state for the buffer material (Lexan). An upper bound for the density of the partial release state can be calculated by integrating the Riemann integral over a linear pressure-volume (P-V) path [Lyzenga and Ahrens, 1978]. For all of the shots, streak camera cutoffs could be observed for the Lexan arrival mirrors mounted on the rear sample surface.

In several experiments, polystyrene foam buffers, as well as Lexan mirrors, were mounted on the rear sample surface to 
observe partial release states. Table 2 summarizes the shock wave equation of state parameters for flyers, drivers, and buffers used in the present study.

\section{RESULTS AND DISCUSSION}

Present experimental results and calculations are listed in Table 3 for the Hugoniot and partial release states determined.

\section{Hugoniot States}

Peak shock pressures achieved ranges between 20 and 142 GPa. The relationship between the shock velocity (Us) and particle velocity (Up) is presented in Figure 1. The data set can be described by a linear regression of the seven points:

$$
\mathrm{Us}_{\mathrm{s}}=\mathrm{C}_{\mathrm{o}}+\mathrm{S} \mathrm{Up}_{\mathrm{p}}
$$

where $C_{o}$ is $4.63 \pm 0.12 \mathrm{~km} / \mathrm{s}$ and $S$ is $1.27 \pm 0.04$. The value of $\mathrm{C}_{\mathrm{o}}$ determined is the same, within experimental errors, as the average value measured by Brillouin scattering techniques for a single-crystal muscovite, the composition of which is similar to ours [Vaughan and Guggenheim, 1986]. The parameters $C_{0}$ and $S$ do not change significantly $\left(C_{0}=4.62 \pm 0.12 \mathrm{~km} / \mathrm{s}\right.$ and $S$ $=1.27 \pm 0.04)$ upon, instead, employing the acoustic value of $C_{0}=4.56 \pm 0.40 \mathrm{~km} / \mathrm{s}$ in the data set. The zero-pressure bulk modulus $\left(\mathrm{K}_{\mathrm{os}}\right)$ and the first pressure derivative $\left(\mathrm{K}^{\prime}{ }_{\mathrm{os}}\right)$ can be calculated using

$$
\begin{aligned}
& K_{o s}=\rho_{o} C_{o}{ }^{2} \\
& K_{\text {os }}^{\prime}=4 S-1
\end{aligned}
$$

They are $60.5 \pm 3.1 \mathrm{GPa}$ and $4.1 \pm 0.2$, respectively.

Pressure-density states attained in the shock compression of muscovite are depicted in Figure 2, and compared with model calculations based upon the assumed Hugoniots for a nonreactive mineral mixture (e.g., $\mathrm{KAlSi}_{3} \mathrm{O}_{8}$ (orthoclase to 30

TABLE 1. Chemical Composition (wt \%) of Muscovite

\begin{tabular}{lrrrrr}
\hline & \multicolumn{5}{c}{ Sample } \\
\cline { 2 - 6 } & 1 & 2 & \multicolumn{1}{c}{3} & \multicolumn{1}{c}{4} & \multicolumn{1}{c}{5} \\
\hline $\mathrm{SiO}_{2}$ & 45.87 & 45.20 & 45.41 & 45.26 & 47.30 \\
$\mathrm{Al}_{2} \mathrm{O}_{3}$ & 38.69 & 38.46 & 38.52 & 38.40 & 36.05 \\
$\mathrm{Na}_{2} \mathrm{O}$ & 0.64 & 0.60 & 0.62 & - & 0.21 \\
$\mathrm{~K}_{2} \mathrm{O}$ & 10.08 & 10.44 & 10.91 & 11.82 & 10.77 \\
$\mathrm{H}_{2} \mathrm{O}$ & 4.67 & 4.64 & 4.53 & 4.52 & 4.9 \\
Total & 99.95 & 99.34 & 99.99 & 100.0 & 99.23 \\
\hline
\end{tabular}

Samples are as follows: (1) Hurlbul [1956]; remainder (not listed) is $0.10 \mathrm{wt} \% \mathrm{MgO}$. (2) Eugster et al. [1972]; remainder (not listed) is $\mathrm{FeO}, \mathrm{Fe}_{2} \mathrm{O}_{3}, \mathrm{MnO}, \mathrm{Li}_{2} \mathrm{O}, \mathrm{TiO}_{2}$, etc. and summed to be about 0.4 wt.\%. (3) Calculated from present idealized muscovite $\left(\mathrm{K}_{0.92} \mathrm{Na}_{0} .08\right) \mathrm{Al}_{3} \mathrm{Si}_{3} \mathrm{O}_{10}(\mathrm{OH})_{2}$. (4) Calculated for pure muscovite $\left(\mathrm{KAl}_{3} \mathrm{Si}_{3} \mathrm{O}_{10}(\mathrm{OH})_{2}\right)$. (5) Vaughan and Guggenheim [1986].
GPa and hollandite above $30 \mathrm{GPa}$ ) $+\mathrm{Al}_{2} \mathrm{O}_{3}+\mathrm{H}_{2} \mathrm{O}$ ) [Al'tshuler and Sharipdzhanov, 1971]) and an oxide mixture (e.g., $\mathrm{K}_{2} \mathrm{O}+\mathrm{Al}_{2} \mathrm{O}_{3}+\mathrm{SiO}_{2}+\mathrm{H}_{2} \mathrm{O}$ ) [Telegin et al., 1980]. In the mineral mixture model calculations, the total volume (V) at a given pressure is calculated to be

$$
\mathrm{V}(\mathrm{P})=\sum_{\mathrm{i}} \mathrm{m}_{\mathbf{i}} \mathbf{v}_{\mathbf{i}}(\mathrm{P})
$$

where $m_{i}$ is a fraction of the individual constituent mineral $i$ with a volume of $v$ at the pressure $P$. The Hugoniots for $\mathrm{KAlSi} \mathrm{O}_{8}, \mathrm{Al}_{2} \mathrm{O}_{3}$, and $\mathrm{H}_{2} \mathrm{O}$ can be found in the literature [Ahrens et al., 1969; Marsh, 1980; Mitchell and Nellis, 1982; Simakov et al., 1974]. Since the Hugoniots for alkali feldspars and plagioclase are insensitive to composition, the feldspar corresponding to the present muscovite can be taken to be microcline, for which the Hugoniot has been determined up to 191 GPa [Simakov et al., 1974]. In Figure 2, the static compression data [Bridgman, 1949] are added to describe the low-pressure region. However, the shock wave data appear to indicate greater compressibility than the static data. A formal fit for equation of state parameters from the 4-GPa static data yields the unrealistic values of $K_{o s}=108 \pm 5 \mathrm{GPa}$ and $\mathrm{K}^{\prime}{ }_{\text {os }}=22 \pm 4$. Thus we did not use the static data in further analysis.

Telegin's model of oxide mixture Hugoniot can be applied to synthesize the muscovite shock data in an approximate range of particle velocities from 2 to $5 \mathrm{~km} / \mathrm{s}$ [Telegin et al., 1980]. This corresponds to a pressure range of 40 to about $150 \mathrm{GPa}$. For multicomponent systems,

$$
U_{s}=C_{o}\left(\rho_{o}, Z\right)+S\left(\rho_{o}, Z\right) U_{p}
$$

where parameters $C_{o}\left(\rho_{0}, Z\right)$ and $S\left(\rho_{0}, Z\right)$ are given from the initial density $\left(\rho_{0}\right)$ of rocks and weight percentage $(Z)$ of oxide constituents in rocks.

$$
\begin{aligned}
& C_{o}=a_{o}+a_{1} \rho_{o}+\sum_{i} Z_{i} a_{i} \\
& S=b_{o}+b_{1} \rho_{o}+\sum_{i} Z_{i} b_{i}
\end{aligned}
$$

where constants $a_{0}, a_{1}, a_{i}$ and $b_{0}, b_{1}, b_{i}$ have been obtained statistically [Telegin et al., 1980].

As seen in Figure 2, the measured densities are in good agreement with the two model calculations in the pressure range of about 80 to $140 \mathrm{GPa}$.

The shock wave data are reduced to an isentrope by applying the third-order Birch-Murnaghan equation of state. The finite strain model is a formalism to analyze the Hugoniot data

\begin{tabular}{|c|c|c|c|c|}
\hline Material & $\begin{array}{c}\text { Initial density } \\
\left(\mathrm{g} / \mathrm{cm}^{3}\right)\end{array}$ & $\begin{array}{c}\text { Us-Up relation } \\
(\mathbf{k m} / \mathbf{s})\end{array}$ & $\begin{array}{c}\text { Measured Range of Up } \\
(\mathrm{km} / \mathrm{s})\end{array}$ & References \\
\hline $\begin{array}{l}\mathrm{Cu} \\
\mathrm{Al}, 1100 \\
\mathrm{Ta} \\
\text { Lexan }\end{array}$ & $\begin{array}{r}8.92 \\
2.712 \\
16.656 \\
1.193\end{array}$ & $\begin{array}{l}U_{s}=3.91+1.51 U_{p} \\
U_{s}=5.38+1.34 U_{p} \\
U_{s}=3.43+1.19 U_{p} \\
U_{s}=2.419+1.321 U_{p} \\
U_{s}=2.449+1.498 U_{p}\end{array}$ & $\begin{array}{c}0.2 \sim 4.2 \\
1.5 \sim 5.1 \\
0.8 \sim 4.9 \\
3.2 \sim 5.2 \\
0.4-28.0\end{array}$ & $\begin{array}{c}1 \\
1,2,3 \\
1 \\
1\end{array}$ \\
\hline $\begin{array}{l}\text { Polystyrene } \\
\text { foam }\end{array}$ & 0.055 & $U_{s}=0.243+1.118 U_{p}$ & $0.2-5$ & 1 \\
\hline
\end{tabular}
[Ahrens and Jeanloz, 1987; Heinz and Jeanloz, 1984; Jeanloz, 1989].

The Eulerian strain $f$ is expressed as

$$
f=0.5\left[\left(\rho / \rho_{o}{ }^{2 / 3}-1\right]\right.
$$

where $\rho$ and $\rho_{0}$ are Hugoniot and ambient densities,

Refere 
respectively. The normalized pressure $F_{H S}$ is given by

$$
F_{H S}=\frac{1-\gamma\left[(1+2 f)^{3 / 2}-1\right] / 2}{3 f(1+2 f)^{3 / 2}[1+(2-1.5 \gamma) f]} P_{H}
$$

where $\gamma$ is the Gruneisen parameter and $\mathrm{PH}_{\mathrm{H}}$ is the Hugoniot pressure.

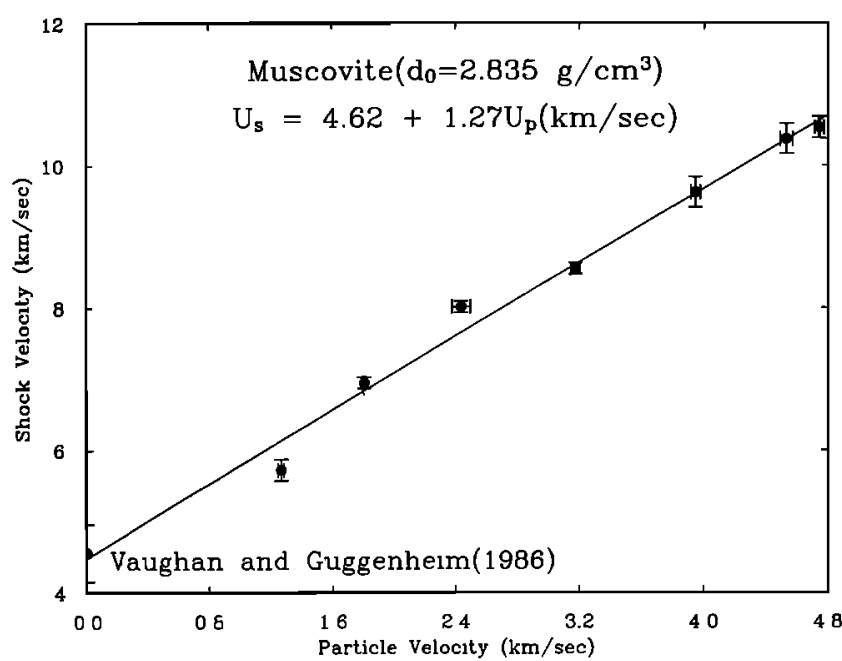

Fig. 1. Shock velocity (Us, $\mathrm{km} / \mathrm{s}$ ) versus particle velocity $(\mathrm{Up}, \mathrm{km} / \mathrm{s})$ for muscovite. Shock velocity at $\mathrm{U}_{\mathrm{p}}=0$ is within the range of acoustic bulk sound velocity for muscovite [Vaughan and Guggenheim, 1986].

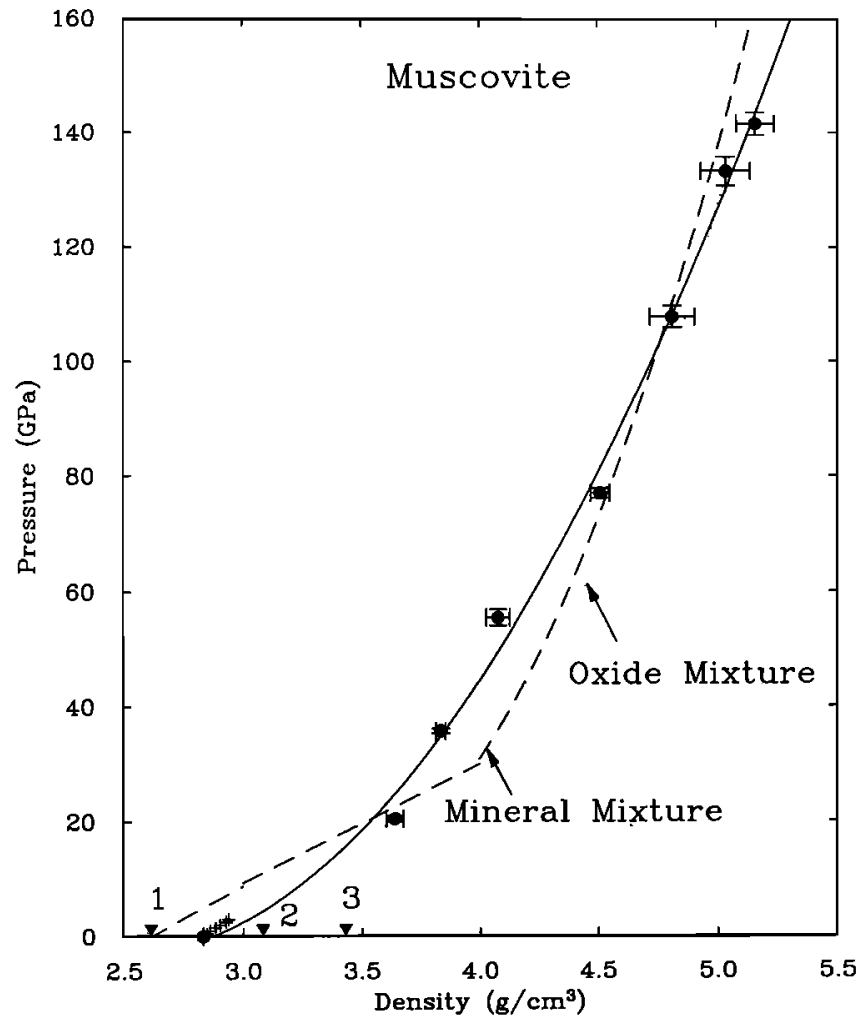

Fig. 2. Pressure-density relations for Hugoniot state of muscovite. Solid circles are from present study, dashed curve is for mineral mixtures, and dotted curve assumes oxide mixture model [Telegin et al., 1980]. Pluses are for the static compression for muscovite [Bridgman, 1949]. The zero-pressure densities at points 1,2 and 3 correspond to mixtures of sanidine $+\mathrm{Al}_{2} \mathrm{O}_{3}+\mathrm{H}_{2} \mathrm{O}$, of wadeite + kyanite $+\mathrm{Al}_{2} \mathrm{O}_{3}+\mathrm{H}_{2} \mathrm{O}$, and of $\mathrm{KAlSi}_{3} \mathrm{O}_{8}$ (hollandite) $+\mathrm{Al}_{2} \mathrm{O}_{3}+\mathrm{H}_{2} \mathrm{O}$, respectively.

$$
\gamma=\gamma_{o}\left(\rho_{o} / \rho\right)^{q} \text { where } \gamma_{o}=\alpha K_{o s} /\left(C_{p} \rho_{o}\right)
$$

$\alpha$ is the volume coefficient of thermal expansion and $C_{p}$ is the specific heat at constant pressure. The value of $\alpha$ for our muscovite is unknown, and we use $\alpha=35 \times 10^{-6} \mathrm{~K}^{-1}$ from a similar muscovite [Guggenheim et al., 1986]. $C_{p}$ is assumed to be approximated by the specific heat at constant volume, $\mathrm{C}_{\mathrm{v}}=0.818 \mathrm{~J} \mathrm{~g}^{-1} \mathrm{~K}^{-1}$, which is given by Robie et al. [1978]. By using $K_{o s}=60.5 \pm 3.1 \mathrm{GPa}$ from the shock wave equations of state, the value of $0.72 \pm 0.04$ is calculated for $\gamma_{0}$. The $q$ values of $1.0 \pm 1.0$ were taken in the present analyses. Without a phase transformation, the internal energy of transformation, $E_{t r}=0$, and a linear least squares fit using (11) to the combined data set, yields the parameters of $\mathrm{K}_{\mathrm{os}}=52 \pm 14 \mathrm{GPa}$ and $\mathrm{K}_{\mathrm{os}}^{\prime}=3.2 \pm 0.3$.

where

$$
F_{H}^{\prime S}=F_{H S}+\Delta F_{t r}=K_{O S}\left(1-2 \xi f_{3} H+\ldots\right)
$$

$$
\begin{gathered}
\xi=3\left(4-\mathrm{K}_{\mathrm{os}}^{\prime}\right) / 4 \\
\Delta \mathrm{F}_{\mathrm{tr}}=\gamma\left(\mathrm{E}_{\mathrm{tr}} / \mathrm{V}_{\mathrm{o}}\right) /(3 \mathrm{f}[1+(2-1.5 \gamma) \mathrm{f}]\}
\end{gathered}
$$

and

$$
\mathrm{f} 3 \mathrm{H}=\mathrm{f}[1+(2-\gamma) \mathrm{f}] /[1+(2-1.5 \gamma) \mathrm{f}]
$$

The present shock wave data of muscovite do not indicate any strong evidence for a rapid transformation to a highpressure phase in the $U_{\mathbf{s}}-U_{p}$ or pressure-density plots. However, the present data cannot exclude the phase transitions which are associated with small volume changes. There are several possible decomposition reactions for muscovite $\left(\mathrm{KAl}_{3} \mathrm{Si}_{3} \mathrm{O}_{10}(\mathrm{OH})_{2}\right)$ as follows:

$$
\begin{gathered}
\mathrm{KAl}_{3} \mathrm{Si}_{3} \mathrm{O}_{10}(\mathrm{OH})_{2}=\mathrm{KAlSi} 3 \mathrm{O}_{8}(\mathrm{Sa})+\mathrm{Al}_{2} \mathrm{O}_{3}+\mathrm{H}_{2} \mathrm{O} \\
\mathrm{KAl}_{3} \mathrm{Si}_{3} \mathrm{O}_{10}(\mathrm{OH})_{2}=\mathrm{KAlSi} 3 \mathrm{O}_{8} \cdot \mathrm{H}_{2} \mathrm{O}(\mathrm{SaHy})+\mathrm{Al}_{2} \mathrm{O}_{3} \\
\mathrm{KAl}_{3} \mathrm{Si}_{3} \mathrm{O}_{10}(\mathrm{OH})_{2}=1 / 2 \mathrm{~K}_{2} \mathrm{Si}_{4} \mathrm{O}(\mathrm{Wad})+ \\
\mathrm{Al}_{2} \mathrm{SiO}_{5}(\mathrm{Ky})+1 / 2 \mathrm{Al}_{2} \mathrm{O}_{3}+\mathrm{H}_{2} \mathrm{O} \\
\mathrm{KAl}_{3} \mathrm{Si}_{3} \mathrm{O}_{10}(\mathrm{OH})_{2}=\mathrm{KAlSi} \mathrm{O}_{8}(\mathrm{Hol})+\mathrm{Al}_{2} \mathrm{O}_{3}+\mathrm{H}_{2} \mathrm{O}
\end{gathered}
$$

where $\mathrm{Sa}$ is sanidine, $\mathrm{SaH}_{\mathrm{y}}$ is sanidine hydrate, Wad is wadeite [Kinomura et al., 1975], $\mathrm{Ky}$ is kyanite, and Hol is hollandite [Ringwood et al., 1967]. The calculated volume changes associated with reactions (15)-(18) are $11.92,-0.27,-11.52$, and $-24.64 \mathrm{~cm}^{3} /$ mole at zero pressure and room temperature. The initial densities are shown in Figure 2 for the decomposition products. Reaction (15) is limited to high temperatures and relatively low pressures [Chatterjee and Johannes, 1974], and reaction (16) is also limited to relatively low temperatures and pressures [Seki and Kennedy, 1964].

To understand the stability of muscovite, a phase diagram was constructed using available thermodynamic data for muscovite and its decomposition products. Thermodynamic data are taken from Robie et al. [1978] and are extrapolated outside their range of applicability to muscovite above $1000 \mathrm{~K}$. Thermodynamic functions for $\mathrm{H}_{2} \mathrm{O}$ were taken from $\mathrm{Halbach}$ and Chatterjee [1982]. Gibbs' free energy values for wadeite $\left(\mathrm{K}_{2} \mathrm{Si}_{4} \mathrm{O}_{9}\right)$ and hollandite $\left(\mathrm{KAlSi}_{3} \mathrm{O}_{8}\right)$ hollandite were computed for the following equilibrium reactions:

$$
\begin{gathered}
2 \mathrm{KAlSi}_{3} \mathrm{O}_{8}(\mathrm{Sa})=\mathrm{K}_{2} \mathrm{Si}_{4} \mathrm{O}_{9}(\mathrm{Wad})+ \\
\mathrm{Al}_{2} \mathrm{SiO}_{5}(\mathrm{Ky})+\mathrm{SiO}_{2} \text { (Coes) }
\end{gathered}
$$


and

$$
\begin{gathered}
\mathrm{K}_{2} \mathrm{Si}_{4} \mathrm{O}_{9}(\mathrm{Wad})+\mathrm{Al}_{2} \mathrm{SiO}_{5}(\mathrm{Ky})+\mathrm{SiO}_{2}(\mathrm{St})= \\
\text { 2KAlSi} 3 \mathrm{O}_{8}(\mathrm{Hol})
\end{gathered}
$$

We approximated the boundary conditions as follows [Liu and Bassett, 1986]:

$$
\mathrm{P}(\mathrm{GPa})=6.3+0.002 \mathrm{~T}\left({ }^{\circ} \mathrm{C}\right)
$$

for reaction (19) and

$$
\mathrm{P}(\mathrm{GPa})=8.3+0.0035 \mathrm{~T}\left({ }^{\circ} \mathrm{C}\right)
$$

for reaction (20), where the effects of both temperature and pressure on volumes were neglected as a first approximation. The resultant equilibrium conditions for reaction (18) are expressed as

$$
\mathrm{P}(\mathrm{GPa})=7.8+0.0047 \mathrm{~T}\left({ }^{\circ} \mathrm{C}\right)
$$

which is shown in Figure 3.

Temperatures along the Hugoniot were calculated using the method of McQueen et al. [1967]. We integrated the equations

$$
\mathrm{dT} / \mathrm{dV}=-\mathrm{T}(\gamma / \mathrm{V})+\left[(\mathrm{dP} / \mathrm{dV})\left(\mathrm{V}_{\mathrm{o}}-\mathrm{V}\right)+\mathrm{P}\right] /\left(2 \mathrm{C}_{\mathrm{v}}\right)
$$

and

$$
d S / d V=\left[(d P / d V)\left(V_{0^{-}} V\right)+P\right] /(2 T)
$$

The resulting shock temperatures are shown in Figure 3. The muscovite Hugoniot is expected to intersect the boundary defined by reaction (18) at about $8 \mathrm{GPa}$. However, the present Hugoniot data obtained for muscovite indicate that muscovite remains present at least up to about $60 \mathrm{GPa}$, where the Hugoniot

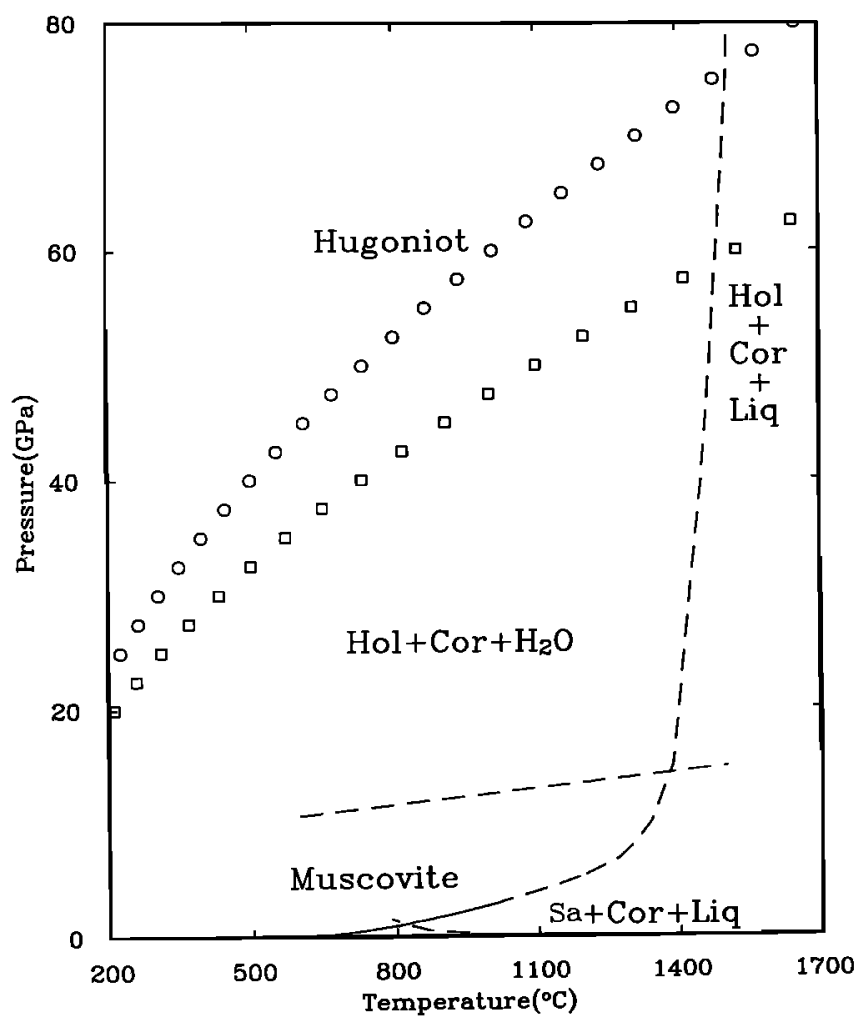

Fig. 3. Pressure-temperature projection of phase boundaries and muscovite Hugoniot. Circles represent the Hugoniot calculation using the heat capacity at $298 \mathrm{~K}$ and squares represent those using the value at 1000 K. Abbreviations: $\mathrm{Hol}$, hollandite (KAlSi $3 \mathrm{O}_{8}$ ), Cor, $\mathrm{Al}_{2} \mathrm{O}_{3} ; \mathrm{Sa}$, sanidine and Liq, liquid. Solid curve was experimentally determined by Huang and Wyllie [1973]. temperature is about $1000^{\circ} \mathrm{C}$. If muscovite decomposes at a lower shock pressure, the Hugoniot is expected to coincide with that of the mineral mixture model above $30 \mathrm{GPa}$ because the constituent, $\mathrm{KAlSi} \mathrm{O}_{8}$, transforms to the hollandite structure [Ahrens and Liu, 1973; Ahrens et al., 1969].

The equilibrium pressure for reaction (17) involving the wadeite phase has a lower pressure than reaction (18). Since there is no indication that the transition to wadeite occurs in the microcline Hugoniot data, it is hard to discuss reaction (17) in the intermediate pressure range.

The equation of state parameters of muscovite $\left(\mathrm{K}_{\mathrm{os}}=52 \pm 4\right.$ $\mathrm{GPa}, \mathrm{K}_{\mathrm{os}}^{\prime}=3.2 \pm 0.3$ ) are comparable with those of brucite [Duffy et al., 1991] $\left(\mathrm{K}_{\mathrm{Os}}=51 \pm 4 \mathrm{GPa}, \mathrm{K}_{\mathrm{os}}^{\prime}=5.0 \pm 0.4\right)$ and serpentine [Tyburczy et al., 1991] ( $\left.\mathrm{K}_{\mathrm{os}}=63.5 \pm 6.7 \mathrm{GPa} ; \mathrm{K}_{\text {os }}^{\prime}=2.75 \pm 0.62\right)$ which have been recently determined. The elasticity measurement of muscovite by the Brillouin scattering technique gave the average bulk sound velocity of $4.56 \pm 0.40 \mathrm{~km} / \mathrm{s}$, [Vaughan and Guggenheim, 1986], which corresponds to a bulk modulus of $59.0 \pm 10.3 \mathrm{GPa}$. This value is consistent with our results. A finite strain analysis of the tremolite Hugoniot data below about $65 \mathrm{GPa}$ [Simakov and Trunin, 1980] yields $\mathrm{K}_{\mathrm{os}}=76 \pm 6 \mathrm{GPa}$ and $\mathrm{K}_{\text {os }}^{\prime}=5.1 \pm 0.5$. The static compression data for portlandite $\left(\mathrm{Ca}(\mathrm{OH})_{2}\right)$, which is isomorphous with brucite, yields $\mathrm{K}_{\mathrm{os}}=37.8 \pm 1.8 \mathrm{GPa}$ and $\mathrm{K}^{\prime}{ }_{\mathrm{os}}=5.2 \pm 0.7$ at room temperature [Meade and Jeanloz, 1990]. It is noteworthy that these hydrous minerals vary greatly in their water content, from about $2 \mathrm{wt} \%$ for tremolite to about $30 \mathrm{wt} \%$ for brucite, but that they have similar equation of state parameters. This comparison assumes they do not transform to high-pressure phase(s).

\section{Partial Release States}

Measured partial release states for muscovite are listed in Table 3 and depicted in Figure 4. Although the shock equation of state for Lexan (buffer material) has been determined only in the Up range up to about $5.2 \mathrm{~km} / \mathrm{s}$ [Marsh, 1980], we used a single linear regression of the high-pressure portion to calculate the observed release states. The release path observed from the lowest Hugoniot pressure of about $20 \mathrm{GPa}$ displays an irregular shape. Taking into account the experimental errors (Table 3), the shock wave may have been attenuated in polystyrene, causing us to measure too low a shock velocity in the buffer. The partial release states obtained from the Hugoniot pressures below $110 \mathrm{GPa}$ indicate that the adiabatic release paths are steeper or have almost the same slopes as the Hugoniot in the density-pressure plane. These steep paths have been interpreted as indicating retention of the denser highpressure phase during the release [e.g., Swegle, 1990]. As seen in Figure 4, however, the release paths from the Hugoniot pressures of 130 to $140 \mathrm{GPa}$ indicate slightly shallower paths than those from the lower pressures. The shallower paths mean that the expected devolatilization during release may have occurred. The local slope of the isentrope upon expansion from a point on the Hugoniot can be approximated [McQueen et al., 1967] by

$$
\left(\frac{\partial \mathrm{P}}{\partial \rho}\right)_{s}=\frac{\rho_{\mathrm{o}}\left(2 \mathrm{~K}_{\mathrm{os}}-\gamma \rho_{\mathrm{H}}^{2} \mathrm{P}_{\mathrm{H}}\right)}{\rho_{\mathrm{H}}\left\{(\gamma+2) \rho_{\mathrm{o}}-\gamma \rho_{\mathrm{H}}\right\}}
$$

The resulting slope obtained shows a simple increase in the slope, as seen in Figure 4. The uncertainty of the calculated slope, however, becomes greater with increasing pressure, and thus it is hard to conclude that the initial slope of isentropic expansion is steeper than that of Hugoniot at high pressures. 
TABLE 3. Hugoniot and Partial Release States of Muscovite

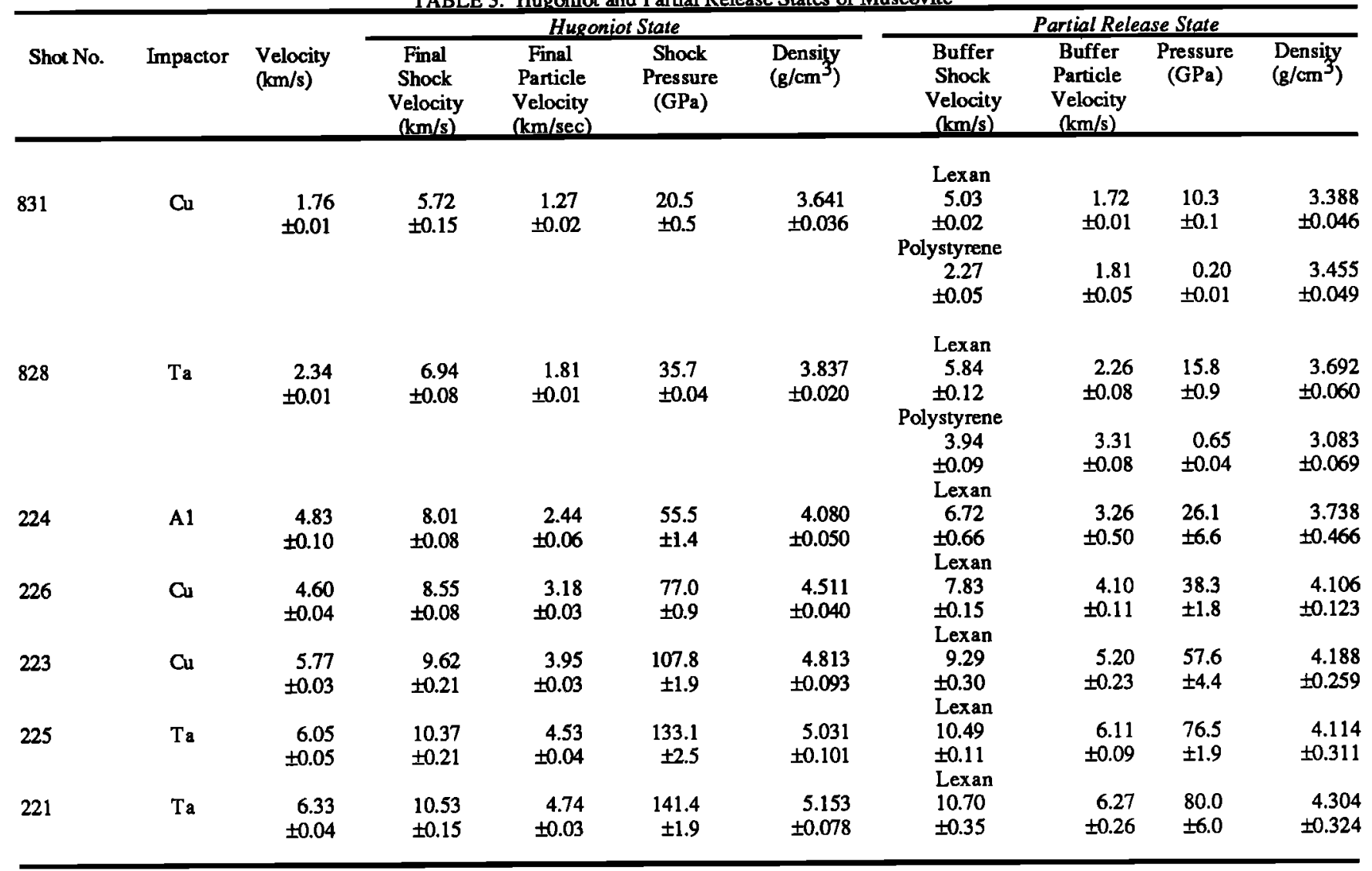

Initial density of muscovite: $2.835 \pm 0.002 \mathrm{~g} / \mathrm{cm}^{3}$.

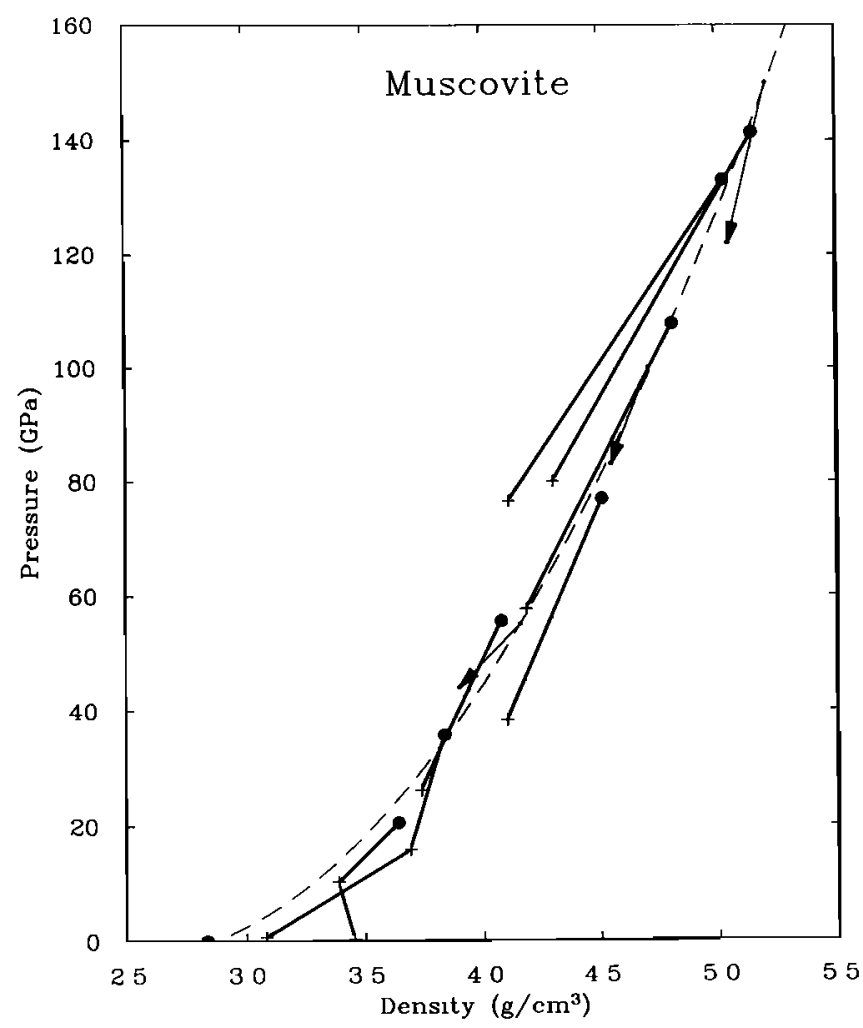

Fig. 4. Pressure-density relations for muscovite showing adiabatic release states. Solid circles are Hugoniot states, and pluses represent measured partial release states (Table 3 ). Solid lines serve only to connect the data sets and are not intended to represent the actual release path. Arrows indicate calculated slopes obtained from equation (26).
According to the investigations of micas in experimentally shocked gneiss [Lambert and Mackinnon, 1984], localized melting of muscovite begins upon release from some $30 \mathrm{GPa}$ and is completed upon release from $\sim 70 \mathrm{GPa}$. Note that the shock melting was congruent and the decomposition products of muscovite were not observed. Moreover, the final shock states in the shock recovery experiments were achieved via multiple reverberation, while those of the equation-of-state experiments were determined under a single shock compression. The final pressures in recovery experiments are those in the stainless steel containers, and the initial shock pressure experienced by the muscovite is calculated to be as low as 10 to $15 \mathrm{GPa}$ in these experiments.

Phase relations of muscovite under static pressure conditions [Huang and Wyllie, 1973] indicate that muscovite decomposes into sanidine, corundum, and vapor below about $1 \mathrm{GPa}$ and 825 ${ }^{\circ} \mathrm{C}$ and that it will melt incongruently above that pressure and temperature. If muscovite melts incongruently upon release from the shock compression, then the structural water in the muscovite may be expelled at considerably lower pressures during the release process. The release states determined here as partially released states are apparently too high in pressure to indicate volatilization. When the pressure of partial release state comes down to the $\sim 1-G P a$ pressure level, we expect shallow release paths and much lower densities. This behavior is observed in the case of brucite [Duffy et al., 1991].

\section{CONCLUSIONS}

1. Shock equation of state data of muscovite are determined between 20 and $140 \mathrm{GPa}$, and can be fit by a linear Us-Up relation: $U s=4.62+1.27 \mathrm{Up}(\mathrm{km} / \mathrm{s})$. 
2. Muscovite apparently remains stable along its Hugoniot. Third-order Birch-Murnaghan equation of state parameters are $K_{o s}=52 \pm 4 \mathrm{GPa}$ and $\mathrm{K}_{\mathrm{os}}^{\prime}=3.2 \pm 0.3$. These parameters are comparable with those of other hydrous minerals such as brucite, serpentine, and tremolite, although the water content varies from 2 to $30 \mathrm{wt} \%$ among these minerals.

3. Thermodynamic and theoretical calculations, however, suggest that muscovite dehydrates into hollandite ( $\mathrm{KAlSi}_{3} \mathrm{O}_{8}$ ), $\mathrm{Al}_{2} \mathrm{O}_{3}$, and $\mathrm{H}_{2} \mathrm{O}$ with only a small volume change above a pressure near $70 \mathrm{GPa}$.

4. Observed release paths indicate a change of the slope in the density-pressure plane near $80 \mathrm{GPa}$, suggesting vaporization upon adiabatic pressure release.

Acknowledgments. We thank Carl Francis of Harvard University for selecting the sample material. We are grateful to Michael Long and Epaprodito Gelle for experimental assistance. We thank R. Jeanloz and D. Walker for helpful reviews. This research was supported under AFGL F19628-88-K-0034, NSF, and NASA. Contribution 4983, Division of Geological and Planetary Sciences, Califomia Institute of Technology.

\section{REFERENCES}

Ahrens, T. J., Shock wave techniques for geophysics and planetary physics, in Methods of Experimental Physics, vol. 24, Part A, edited by C. G. Sammis and T. L. Henyey, pp. 185-235, Academic Press, San Diego, Calif., 1987.

Ahrens, T. J., and R. Jeanloz, Pyrite: Shock compression, isentropic release, and composition of the Earth's core, J. Geophys. Res., 92, 10363-10375, 1987.

Ahrens, T. J., and H.-P. Liu, A shock-induced phase change in orthoclase, J. Geophys. Res., 78, 1274-1278, 1973.

Ahrens, T. J., C. F. Peterson, and J. T. Rosenberg, Shock compression of feldspars, J. Geophys. Res., 74, 2727-2746, 1969.

Al'tshuler, L. V., and I. I. Sharipdzhanov, Additive equations of state of silicates at high pressures, Izv. Earth Phys., Engl. Transl., 3, 11-28, 1971.

Bridgman, P. W., Linear compressions to $30,000 \mathrm{~kg} / \mathrm{cm}^{2}$, including relatively incompressible substances, Proc. Am. Acad. Arts Sci., 77, 189-234, 1949.

Brown, J. M., and J. W. Shaner, Rarefaction velocities in shocked tantalum and the high pressure melting point, in Shock Waves in Condensed Matter-1983, edited by J. R. Asay, R. A. Graham and G. K. Straub, pp. 91-94, Elsevier, New York, 1984.

Chatterjee, N. D., and W. Johannes, Thermal stability and standard thermodynamic properties of synthetic $2 \mathrm{M}$-muscovite, $\mathrm{KAl}_{2}\left[\mathrm{AlSi}_{3} \mathrm{O}_{10}(\mathrm{OH})_{2}\right]$, Contrib. Mineral. Petrol., 48, 89-114, 1974.

Cummings, D., Shock deformation of biotite around a nuclear explosion, in Shock Metamorphism of Natural Materials, edited by B. M. French and N. M. Short, pp. 211-218, Mono, Baltimore, Md., 1968.

Duffy, T. S., T. J. Ahrens, and M. A. Lange, The shock wave equation of state of brucite $\mathrm{Mg}(\mathrm{OH})_{2}, J$. Geophys. Res., 96, 14,319-14,330, 1991.

Eugster, H. P., A. L. Albee, A. E. Bence, and J. B. Thompson, Jr., The two-phase region and excess mixing properties of paragonitemuscovite crystalline solutions, J. Petrol., 13, 147-179, 1972.

Guggenheim, S., Y. Chang, and A. F. Koster van Groos, Muscovite dehydroxylation: High-temperature studies, Am. Mineral., 72, 537$550,1986$.

Halbach, H., and N. D. Chatterjee, An empirical Redlich-Kwong-type equation of state for water to $1000^{\circ} \mathrm{C}$ and $200 \mathrm{Kbar}$, Contrib. Mineral. Petrol., 79, 337-345, 1982.

Heinz, D. L., and R. Jeanloz, The equation of state of the gold calibration standard, J. Appl. Phys., 55, 885-893, 1984.

Hörz, F., and T. J. Ahrens, Deformation of experimentally shocked biotite, Am. J. Sci., 267, 1213-1299, 1969.

Huang, W. L., and P. J. Wyllie, Muscovite dehydration and melting in deep crust and subducted oceanic sediments, Earth Planel. Sci. Letl., $18,133-136,1973$.

Hurlbut, C. S., Jr., Muscovite from Methuen Township, Ontario, Am. Mineral., 41, 892-898, 1956.
Jackson, I., and T. J. Ahrens, Shock-wave compression of single crystal forsterite, J. Geophys. Res., 84, 3039-3048, 1979.

Jeanloz, R., Shock wave equation of state and finite strain theory, $J$. Geophys. Res., 94, 5873-5886, 1989.

Jeanloz, R., and T. J. Ahrens, Pyroxenes and olivines: Structural implications of shock-wave data for high pressure phases, in HighPressure Research: Applications to Geophysics, edited by M. H. Manghnani and S. Akimoto, pp. 439-462, Academic Press, San Diego, Calif., 1977.

Kinomura, N., S. Kume, and M. Koizumi, Synthesis of $\mathrm{K}_{2} \mathrm{SiSi}_{3} \mathrm{O}_{4}$ with silicon in 4- and 6-coordination, Mineral. Mag., 40, 401-404, 1975.

Lambert, P., and I. D. R. Mackinnon, Micas in experimentally shocked gneiss, Proc. Lunar Planet. Sci. Conf. 14th, J. Geophys. Res., 89, Suppl. B685-B699, 1984.

Liu, L., and W. A. Basselt, Elements, Oxides, and Silicates, Oxford University Press, New York, 1986.

Lyzenga, G. A., and T. J. Ahrens, The relation between the shockinduced free surface velocity and the post-shock specific volume of solids, J. Appl. Phys., 49, 201-204, 1978.

Marsh, S. P. (Ed.), LASL Shock Hugoniot Data, pp. 1-327. University of Califomia Press, Berkeley, 1980.

McQueen, R. J., S. P. Marsh, and J. N. Fritz, Hugoniot equation of state of twelve rocks, J. Geophys. Res., 72, 4999-5036, 1967.

Meade, C., and R. Jeanloz, Static compression of $\mathrm{Ca}(\mathrm{OH})_{2}$ at room temperature: Observations of amorphization and equation of state measurements to $10.7 \mathrm{GPa}$, Geophys. Res. Lett., 17, 1157-1160, 1990.

Mitchell, A. C., and W. J. Nellis, Equation of state and electrical conductivity of water and ammonia shocked to the $100 \mathrm{GPa}$ (1 Mbar) pressure range, J. Chem. Phys., 76, 6273-6281, 1982.

Ringwood, A. E., A. F. Reid, and A. D. Wadlsey, High-pressure $\mathrm{KAlSi}_{3} \mathrm{O}_{8}$, an aluminosilicate with six-fold coordination, Acta Crystallogr. 23, 1093-1095, 1967.

Robie, R. A., B. S. Hemingway, and J. R. Fisher, Themodynamic properties of minerals and related substances at $298.15 \mathrm{~K}$ and 1 bar $\left(10^{5}\right.$ pascals) pressure and at higher temperatures, U.S.Geol.Surv. Bull. 1452, 456, 1978.

Seki, Y., and G. C. Kennedy, The breakdown of potassium feldspar $\mathrm{KAlSi}_{3} \mathrm{O}_{8}$ at high temperatures and high pressures, Am. Mineral., 49, $1688-\Gamma^{7} 706,1964$.

Short, N. M., Experimental microdeformation of rock materials by shock pressures from laboratory-scale impacts and explosions, in Shock Metamorphism of Natural Materials, edited by B. M. French and N. M. Short, pp. 219-242, Mono, Baltimore, Md., 1968 a.

Short, N. M., Nuclear-explosion-induced microdeformation of rocks: An aid to the recognition of meteorite impact structures, in Shock Metamorphism of Natural Materials, edited by B. M. French and N. M. Short, pp. 185-210, Mono, Baltimore, Md., $1968 b$.

Simakov, G. V., and R. F. Trunin, The compression of minerals by shock waves, Izv. Earth Phys., Engl. Transl., 16, 134-137, 1980.

Simakov, G. V., N. M. Pavlovsky, N. G. Kalashnikov, and R. F. Trunin, Shock compressibility of twelve minerals, Izv. Acad. Sci. USSR Phys. Solid Earth, Engl. Transl., 10, 11-17, 1974.

Swegle, J. W., Irreversible phase transition and wave propagation in silicate materials, J. Appl. Phys., 68, 1563-1579, 1990.

Telegin, G. S., V. G. Antoshev, V. A. Bugayeva, G. V. Simakov, and R. F. Trunin, Calculated determination of Hugoniot curves of rocks and minerals, Izv. Earth Phys., Engl. Transl., 16, 319-324, 1980.

Tyburczy, J. A., T. S. Duffy, and T. J. Ahrens, Shock wave equation of state of serpentine to $150 \mathrm{GPa}$ : Implications of the occurrence of water in the Earth's lower mantle, J. Geophys. Res., 96, 18011-18027, 1991.

Vaughan, M. T., and S. Guggenheim, Elasticity of muscovite and its relationship to crystal structure, J. Geophys. Res., 91,4657-4664, 1986.

T. J. Ahrens, Seismological Laboratory 252-21, California Institute of Technology, Pasadena, CA 91125.

A. M. Rubin, Department of Geological Sciences, Brown University, Providence, RI 02912.

T. Sekine, National Institute for Research in Inorganic Materials, Tsukuba, lbaraki 305, Japan.

(Received February 20, 1991; revised August 5, 1991; accepted August 28, 1991.) 